\title{
Discussion on whole-process management of fixed assets in colleges
}

\section{and universities}

\author{
Fang Peng WU \\ Wuhan Business University, Wuhan, Hubei Province
}

KEYWORD: Colleges and universities; Fixed assets; Whole-process management

\begin{abstract}
There are many problems about management of fixed assets in colleges and universities in China. This article analyzes the causes of these problems and then puts forward whole-process management of fixed assets which will help colleges and universities strengthen their scientific management of fixed assets. It will have a reasonable and effective effect on fixed assets and provide material support to colleges and university in terms of teaching, scientific researches and students' activities. It will also achieve a reasonable allocation of fixed assets and constantly promote steady development of colleges and universities.
\end{abstract}

Management of fixed assets is an important part for colleges. Its main task is to have effective supervision in the aspects of allocation and using of fixed assets and property rights in order to improve the efficiency of fixed assets and reduce the loss which will achieve the ultimate goal of an optimal allocation, specific property rights, efficient practicalities and comprehensive monitoring, maximizing the utility of fixed assets. Good management of fixed assets in colleges will lay a good material foundation for teaching and scientific researches and provide necessary conditions for the cultivation of innovative talents. Bad management of fixed assets will cause problems, like the loss, waste and low efficiency of fixed assets.

\section{DEFINITION OF WHOLE-PROCESS MANAGEMENT OF FIXED ASSETS}

Whole-process management, based on the whole-process of network service, is a systematic process of segmented and combined management from purchasing plans to procurement to usage to becoming useless. The whole-process of network services needs to establish a network environment. It will connect different stages of the whole-process management of fixed assets with fixed assets information in secondary departments to achieve trans-department and database functions.

The whole-process management of fixed assets is a whole process of management and effective monitoring of purchasing plans, procurement, inspection, maintenance, repair, usage, discarding, which is based on network service by improving fixed assets management system. Meanwhile perfect fixed assets archives and electronic database should be established to improve the efficiency of management. The specific management of fixed assets in colleges and universities should be implemented by secondary departments based on unified management and even by each individual, so that each management stage can interact and have mutual supervision.

\section{THE ANALYSIS OF REASONS FOR WHOLE-PROCESS MANAGEMENT OF FIXED ASSETS IN COLLEGES AND UNIVERSITIES}

\subsection{Old-fashioned management model of fixed assets among college leaders}

Some college leaders keep old-fashioned management model of fixed assets in mind and they think that the country will never have colleges unmanaged at all times and it is only a matter of the money it will invest. A country's fixed assets investment should be managed by the country, colleges do not need to spend too much energy in the management of fixed assets. Such ideas won't have much influence on general staff, but if decision makers in colleges have the ideas, it will make the fixed assets management system old-fashioned. The drawbacks of the existing fixed assets management will exist for a long time and will not disappear. 


\subsection{Indistinct system of fixed assets allocation and the allocation methods in colleges and universities}

There are mainly two types of fixed assets allocation: One is the allocation for special projects. Special funds are given by higher authorities or colleges for purchasing and construction because of the disciplinary construction, project reconstruction, laboratory standards, and an upcoming assessment and so on. This allocation method often invests more funds at a time and purchases higher fixed assets for construction. However, it is easy to expand the quantity of assets demand, raise the grade of equipment and even purchase irrelevant equipment to render it unused or wasted. The other allocation method is the supply system of fixed assets in colleges and universities, according to their "demand". It is allocated based on the actual needs of teaching and scientific researches, and the administrative planning of colleges. It doesn't include depreciation or charge for use. Once allocated, the unit can have access for the entire time. Even if the efficiency of fixed assets is not high and the allocation is not reasonable, the unit is not liable. The above two allocation methods don't share fixed assets so they can't be fully used.

\subsection{Lack of attention among college managers on the usage of fixed assets}

Colleges and universities' fixed assets are owned by the country or by all the people. Because of the characteristics of public property, losses or gains of fixed assets are not affected for every manager. That's to say, the losses and gains of fixed assets in colleges and universities can be allocated by all the people, the proportion for each individual is extremely small, which leads to a lack of supervision and incentive mechanism for managing state-owned assets in colleges and universities. Fixed assets in colleges are not run for operation, which makes some managers become formalistic on management and have inattentive supervision. As public institutions mainly relying on the state funding, the assets become private property for a unit or a department. So a majority of managers only pay attention to the purchase of fixed assets and neglect management.

\subsection{Multiple management of fixed assets}

Many colleges and universities in China still use a traditional mode for fixed assets managementmultiple management of fixed assets. Logistics department manages building property; equipment department is responsible for teaching and scientific research equipment; resources administrative office manages fixed assets of college-run industries; financial department manages current assets. This management mode will result in repeated management or mutual evasiveness of responsibilities and have loopholes in management though there are many functional departments for the management of fixed assets. Repeated management will increase the cost of management and lack of management will have loopholes, which tend to cause the loss of fixed assets. Because a more perfect management mode of fixed assets is not formed to achieve unified leadership, centralized management, graded responsibilities and responsibility for each individual, the authority of the management of fixed assets is weakened in a certain extent.

\subsection{Fixed assets only focus on macro management}

It was discovered through research on rules and regulations of fixed assets management in some colleges and universities that they have comprehensive rules and regulations of public management but they don't form a system for specific operational measures of the fixed assets management, especially lack of measures on responsibilities for each individual. So individuals still have an oldfashioned thinking set because they attach great importance to fixed assets in the accounts and ignore specific management measures. When managers for fixed assets are replaced, it's difficult to find out who is responsible for the loss of fixed assets because there are only accounts without any detailed information.

\section{KEY POINTS OF WHOLE-PROCESS MANAGEMENT OF FIXED ASSETS}

\subsection{The stage of purchasing plans of fixed assets}

Planning is an important stage in the whole-process management mode. According to government's regulations for procurement in colleges and universities, different departments are required to draw up a budget for next year on the second half of each year. Each department should make a feasible 
analysis based on the demand for teaching and development to draw up project constructions and annual purchasing plans of fixed assets.

When all the departments in colleges are drawing up the next year's purchasing plans of fixed assets, on the one hand, department staff for assets management should go to offices, teaching and research sections and training rooms to carry out research and get statistical results on fixed assets which have ended their service life or have been damaged that can't be used or equipment that can't meet the requirements for teaching; on the other hand, managers have to enter information systems of fixed assets management to look up information of each department and check whether fixed assets have reached a discarded period. At the same time, to check whether colleges have similar fixed assets that can be used through a three-dimensional positioning system on the campus. If they have, it's necessary to find out whether those assets can be deployed or shared and there's no need to purchase them. Those that can't be shared or deployed should be added into the plan. Managers for the department assets can present a report through the information system of purchasing fixed assets. Purchasing departments collect all the information, make a list in accordance with the order of importance and report it to the financial system. Financial sectors have to examine and approve according to the annual budget and give feedback to the college assets department.

\subsection{The stage of procurement of fixed assets}

The procurement stage in the mode of whole-process management attaches great importance to sharing and transmitting information among relevant departments. Procurement departments make purchases according to the specific information. Different ways of bidding and purchasing will be chosen due to different purchasing amounts in order to purchase equipment that can meet requirements for teaching and save state-owned funds. Departments can look into the purchasing management system to learn about information on procurement items and to submit or modify technical parameters of the procurement of fixed assets according to the requirements of the procurement department. When calling for bidding, the system for procurement management announces a bidding notice. The application department can send experts to participate in the bidding. After the bidding, bid-winning announcement will be released. Representatives from purchasing and operating departments sign a contract, and then the purchase of fixed assets and examination will be implemented. Payment information is submitted to financial departments. Purchasing information is updated in every step of the procurement so that application departments, leaders and supervision departments can browse relevant information at any time and give feedback when necessary.

\subsection{The stage of usage of fixed assets}

Colleges and universities should implement two-level management mode of fixed assets. Fixed assets administrative offices are the first level administrative departments and faculty departments are the second level administrative units. The latter can divide responsibility to each individual, namely, colleges and universities can adopt a management system in order to realize unified leadership, two-level management, and division of responsibility to each individual.

Management departments of fixed assets in colleges and universities should distribute responsibilities and obligations. They should supervise and manage the second level departments of fixed assets and maintain the integrity, rational allocation and effective use of fixed assets. In the process of fixed assets management, information management center of colleges should share information and data about fixed assets management between the first level and the second level departments. When the fixed assets of departments have been checked, it comes to the stage of usage, including daily maintenance and maintenance management. Information about purchasing fixed assets has been saved in the system, like the purchasing date, departments, managers, users, production date, product's name, type and value, etc. It can automatically generate labels and can also use the three dimensional positioning system to locate positions. The main function of management is to provide service. Its main task is to make the fixed assets work properly during the limited lifetime, provide maintenance and repair for teaching, scientific researches and administrative work and provide useful information for planning, procurement, discarding. 


\subsection{The stage of discarding of fixed assets}

Departments having used fixed assets should present discarding application. Fixed assets management departments have to check the application, and then present it to leaders and higher authorities to deal with it. The discarding stage is the final one. Departments having used fixed assets can apply for equipment discarding through the system of fixed assets management. The first level fixed asset managers can check details of the equipment to find out whether it meets discarding conditions. If the information system of fixed assets shows that it meets the discarding conditions, discarding procedures can be carried out; if not, the second level departments put forward discarding. Fixed assets management departments of the college organize a checking team to verify the information on site. Fixed assets that can meet the need of teaching and office work should be allocated to other departments; if the equipment has to be discarded in advance because of out-dated technology, it can be auctioned.

Therefore, colleges and universities implement the whole-process management of fixed assets; work efficiency will be greatly improved. The second level departments with the help of network can submit an application which will be checked by leaders and can carry out procurement, management and discarding. Fixed assets can be allocated effectively to achieve information sharing which will dramatically improve management efficiency.

This paper is a scientific research project of Wuhan Business University in 2016-Research on two-level management of fixed assets in colleges and universities based on a case study of Wuhan Business University. Project number: 2016KY038

\section{REFERENCES}

- Lan Gushan: Problems and countermeasures of fixed assets management in the newly established colleges and universities, Master's thesis of Guangxi University

- Wei Shanlin: Research on the mode of fixed assets management in universities in Guangdong Province based on financial budget [D], Master's thesis of Guangdong University of Technology, 2011.11

- Luo Zhiliang: A brief analysis of Berkeley University's assets management [J], Logistics Research in China's Universities, 2001 (2)

- Li Huisheng: Research on assets management in colleges and universities [M], University of Science and Technology of China Press, 2007.2

- Wu Hongwei: Research on the management of non-operating state-owned assets [M], Law Press, 2010.4 